\title{
Introduction to Information Literacy: An Online Library Media Course for High School Students
}

\author{
Margaret Lincoln \\ Library Media Specialist \\ Lakeview High School \\ USA
}

\begin{abstract}
During the academic year 2007-2008, a hybrid online course was piloted at Lakeview High School in Battle Creek, Michigan. The course was created in response to a newly mandated Michigan Department of Education online learning graduation requirement. Blackboard Learning Management System was utilized for instruction. The curricular focus was information literacy. Students included 11th and 12th graders who also gained real world library work experience. In the new online learning environment, library media specialists are creating an infrastructure to support the dynamic and evolving ways that students and teachers use information resources.
\end{abstract}

School Libraries, Online Learning, Information Literacy

\section{Introduction}

As technology advances continue to impact K-12 schools, online education options are offering alternative choices and venues for teaching and learning. School libraries, long committed to providing physical and intellectual access to instructional materials, are already responding to changing student and teacher needs in the online world. For example, many school libraries that had previously created a virtual presence through a fixed library website are now incorporating such Web 2.0 features as blogs and wikis into the library's online space (Richardson, 2007). In seeking to define their role in the new realm of virtual learning, library media specialists will need to address an essential question: How can an effective infrastructure be established in the online environment so as to support the dynamic and evolving ways that students and teachers use information resources? The involvement of school libraries in the development of online courses suggests a possible means to meet this challenge.

During the academic year 2007-2008, a hybrid or blended online course including faceto-face meetings was piloted at Lakeview High School in Battle Creek, Michigan. The course was created in response to newly mandated Michigan Department of Education (MDE) online learning graduation requirement. The curricular focus was information literacy. Blackboard Learning Management System was utilized for instruction. Eleventh and twelfth grade students enrolled in the course also gained real world library media center work experience. Additionally, various online information literacy activities from the Blackboard course were incorporated into instructional units taught in other academic departments at Lakeview High School. 
Initially determined to have been a successful undertaking, the Introduction to Information Literacy course will be offered again to students in the upcoming school year. The International Association of School Librarianship Conference thus affords the opportunity to share the Lakeview venture into online learning with other school library media professionals who may be involved in similar projects. This paper first presents background information on school libraries and online learning by means of a short literature review. The circumstances surrounding the state of Michigan's online learning requirement will be considered. Subsequent portions of the paper will examine how the information literacy course at Lakeview High School was designed, implemented and disseminated.

\section{School Libraries and Online Learning}

\section{Growth of Online Learning}

Online learning in the K-12 environment has seen sustained, dramatic growth across the nation with 38 states now having established state-led online learning programs, policies regulating online learning, or both (Armstrong, 2007). State Legis/atures (2007) reported that 25 states had set up state-wide virtual schools while 18 states had 65,354 students attending 147 virtual charter schools. A U.S. Department of Education (2007) publication highlighted providers of online advanced academic courses in six states. Yet it was Michigan that became the first state to actually legislate an online learning requirement for high school students (Ishizuka, 2006).

Although the increase in online learning projects is well-documented in the literature, fewer instances have been reported as to how school libraries have become involved in this growing trend. The September/October 2005 issue of Knowledge Quest, however, was devoted to new roles that school librarians are assuming in digital learning environments. In this issue, Abilock (2005) pointed out that students may be considered digital natives and multitaskers but should not learn exclusively from superficial experiences. Students will learn well in real and virtual environments if school librarians participate in the design, development, implementation, support, and assessment of learning. Dando (2005), an early adapter of online course management systems, reported using Blackboard to measure students' information skills during library orientation, to provide students with access to key resources, and to make library announcements. A further function taken on by media specialists in support of online learning is to serve as a mentor to teachers, helping colleagues to acquire the technological and research skills necessary to deliver dynamic and relevant online courses (Rohland-Heinrich \& Jensen, 2007). Media specialists can work with teachers to direct students to discipline-specific and quality sources intended to strengthen the virtual learning experience for students.

\section{Information Literacy}

Ensuring that students are effective users of ideas and information is a paramount instructional goal of online courses. The need to teach information literacy and critical thinking skills is consistently called for in the educational literature. Schools and academic libraries take on a pivotal role in reinforcing these skills which are vital to students in an informationoverloaded world (Battle, 2007). Media specialists should actively promote information literacy standards, demonstrating a direct connection to improved education and higher test scores (Yohe, 
2007). But techno-savvy is not synonymous with information literate. A University of Oklahoma study recommended that information literacy instruction must be relevant to students' lives and must mesh with their learning styles (Brown et al., 2003). Although focused at the college level, this study has applicability for the high school curriculum where an attempt is made to include differentiated instruction. A recent British study also overturns the common assumption that the 'Google Generation' - youngsters born or brought up in the Internet age - is the most webliterate. The first ever virtual longitudinal study carried out by the CIBER research team at University College London claims that, although young people demonstrate an apparent ease and familiarity with computers, they rely heavily on search engines, view rather than read and do not possess the critical and analytical skills to assess the information that they find on the web (British Library, 2008).

Library media specialists are therefore challenged to effectively integrate information literacy skills into online learning. How can this best be accomplished? According to Esch and Crawford (2006), students should early on be exposed to a university-level online database system with access to both professional and scholarly journals so as to lessen transitional anxiety between high school and college research assignments. Novotny and Cahoy (2006) reported on a usability study that explored how students search the library's online catalog after they have received library instruction. Evidence suggests that instruction tied into students' current research assignments can have a positive effect on user search behaviors and unnecessary details should be curtailed so as to not promote the boredom factor. Scott and O'Sullivan (2005) studied student search strategies to make a case for integrating information literacy skills into all areas of a school's curriculum, not just in library orientation classes or in isolated skills presentations so that students can become more skillful at navigating the hypertext environment of the Web. Improvement in information literacy skills can now even be assessed using TRAILS (Tool for Real-time Assessment of Information Literacy Skills), a freely available online tool created by academic librarians at Kent State University (Schloman \& Gedeon, 2007). A library media specialist can thus obtain a snapshot of skill levels in order to better tailor instructional efforts and can access additional support for information literacy instruction through a TRAILS Wiki set up at http://ilfortrails9.wikispaces.com/. But while cognitive skills often take precedence in an outcomes-based, standards-driven curriculum, Cahoy (2002) found that the ability to recognize and manage feelings, especially while navigating the research process, is an affective skill that students must master in order to become information literate. The course structure and logistics of the online introductory information literacy class at Lakeview High School did foster a more personal learning environment where affective competencies could be addressed.

\section{Course Content Management}

Once a commitment is made to establish an online course that reinforces information literacy skills, the matter of effective course design and choice of content management system must be considered. A study by Bauer and Kenton (2005) reported that even highly educated and technology adept teachers are not always able to integrate technology on a consistent basis as a teaching and learning tool. Two key issues were that their students did not have enough time at computers, and that teachers needed extra planning time for technology lessons. The use of Blackboard in a blended course environment may help to address these identified problems in that the content management system can be accessed from school and home by students and by 
the library media specialist. The benefits of the blended or hybrid approach to an online course are also recognized by Tallman and Fitzgerald (2005) who favor the mix of online and face-toface instruction. Similarly, Kachel, Henry and Keller (2005) look upon the hybrid online course as the best choice at the high school level, providing extra direction and added motivation needed by secondary school students. These authors emphasize that a good online course must go far beyond a read-this-and-respond correspondence course to an environment where students are actively engaged in authentic learning activities. A module, for example, can begin with a video clip or a short scenario of a situation illustrating the module's content.

Educational advantages of Blackboard as a content management system should be mentioned. Jackson (2007) points out that Blackboard may be used to scaffold instruction and infuse information literacy activities throughout subject-specific courses, avoiding one-shot inperson library instruction sessions and instead, encouraging students to become lifelong learners. Lang (2007) acknowledges that Blackboard facilitates communication with and between students through e-mail, messaging, and discussion boards; helps an instructor manage paperwork and grading; and provides a convenient place to store and retrieve all course-related documents. According to Pappas (2002), library media specialists and classroom teachers can use the discussion board feature of Blackboard in a collaborative way to reinforce information literacy skills, directing students to an organized, threaded arrangement of topics. Giles (2004) writes from the perspective of a college librarian but still shares a useful observation. Involvement in a Blackboard course allows a librarian to interact more extensively with students online rather than simply deliver a stand-alone lecture on finding relevant information sources. Finally, although online teaching is demanding and time-intensive (Tomei, 2006), adopting to the challenges of using a course content management system can often bring about a renewed excitement for teaching (West, Waddoups, \& Graham, 2007).

\section{The State of Michigan's Online Learning Requirement}

Under the collaborative leadership of Governor Jennifer M. Granholm, the State Board of Education, and the State Legislature, landmark state graduation requirements have been implemented to give Michigan students the knowledge and skills to succeed in the 21st Century and drive Michigan's economic success in the global economy. One of the requirements is that beginning with the graduating class of 2011, all high school students will have had a successful online learning experience (MDE, 2006a). The new Michigan Merit Curriculum also makes it mandatory for high school graduates to have earned 16 academic credits, including four credits in both Mathematics and English Language Arts. For the class of 2016, two credits in World Languages will be required.

The rationale justifying the online learning requirement is that such an experience will prepare students for the demands that they will encounter in higher education, the workplace, and in personal life-long learning. While students informally develop technology skills and gain experience through their media-rich lives, an online learning experience will require them to complete assignments, meet deadlines, learn appropriate online behavior, and effectively collaborate with others in an instructional setting. Michigan's online learning requirement is consistent with one of the core recommendations contained in the U.S. Department of Education's National Education Technology Plan which stipulates that schools should provide 
every student access to e-learning (U.S. Department of Education, 2004). The online learning requirement is also aligned with the State Educational Technology Plan adopted by the Michigan State Board of Education in March 2006 (MDE, 2006c). A key recommendation contained in this document states: "Every Michigan student will have meaningful technology-enabled learning opportunities based on research and best practice that include virtual learning experiences." (p.ii)

Local school districts have been aided in their efforts to plan for integration of the new online learning requirement through the support of MDE. Table 1 summarizes key documents which have been made available through MDE and which offer important background about the learning requirement.

Table 1

Key Michigan Department of Education Documents

Document Purpose, Date, Location

Michigan Merit

Curriculum Guidelines

for Online Learning
This guide was developed to assist teachers in successfully implementing the Michigan Merit Curriculum. The identified content expectations and guidelines provide a useful framework for designing curriculum, assessments and relevant learning experiences for students. The document includes a definition, rationale, delivery formats for online learning which can be teacher-led, blended instruction, teacher facilitated, self-paced. Technology requirements are listed. October 2006. Available at http://www.michigan.gov/documents/mde/Online10.06 final 175750 7.pdf

Online Experience Guideline Companion Document

This document identifies three manners in which a student can have a meaningful online learning experience: online courses; online learning experiences; or online learning incorporated into each of the required credits. December 2006. Available at

http://www.michigan.gov/documents/mde/OE Companion Doc 12-

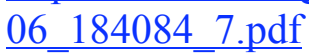

Michigan Merit Curriculum High School Graduation Requirements

The Frequently Asked Question (FAQ) document was designed to provide readers with information and clarification regarding state graduation requirements, including the online learning requirement. March 2008. Available at http://www.michigan.gov/documents/mde/FAQ Entire Document 12.07 217841 7.pdf.

Michigan Educational Technology Standards \& Expectations
Standards are aligned with International Society for Technology in Education's (ISTE) National Educational Technology Standards for Students (NETS-S). To be integrated into other content areas with release of supplementary document with suggestions and examples. January 2006. Available at http://www.michigan.gov/documents/9-12_150927_7.pdf. 
To supplement the online learning assistance given to school districts by MDE, the organization of statewide Regional Media Centers or REMCs has developed several important initiatives. For example, the Technology Enhanced Lesson Plans project has allowed educators to participate in summer academies each year since 2006. See http://techplan.edzone.net/ci2007/. Attendees have created technology integrated lessons exemplifying best practice and universal design principles while also correlating with the Michigan Educational Technology Standards (METS), Grade Level Content Expectations (GLCEs) and High School Content Expectations HSCEs). The lessons are accessible online and searchable by content standards through the Michigan Educators' Resources (MER) site at http://mel.org/mer/SPT--BrowseResources.php. a project of the Library of Michigan, MDE, and Wayne State University. Another REMC backed project is GenNET Online Learning at http://gennetonline.geneseeisd.org/profile.htm which offers online learning courses to high school and middle school students from over eight accredited distance learning providers. Michigan Virtual University should not be overlooked for also making online courses available to students throughout the state and for creating the CareerForward ${ }^{\mathrm{rM}}{ }^{*}$ course in partnership with MDE and Microsoft Corporation. The course has helped Michigan students understand how to plan for their work lives and career opportunities amid the implications of the global economy. CareerForward has been an effective means for Michigan students to satisfy the Michigan Merit Curriculum online learning requirement.

\section{Course Design}

\section{State Guidelines and Essential Characteristics}

Lakeview High School's Introduction to Information Literacy was conceived as a blended course offering an online virtual learning environment through Blackboard Learning Management System and onsite practical work experience in a library setting. A student electing this course would acquire knowledge about and practical experience in library operations so as to enhance his/her lifelong personal and professional use of libraries. The student would engage in project-based learning activities designed to develop $21^{\text {st }}$ century information literacy skills.

The previous section of this paper discussed the Michigan Merit Curriculum online learning requirement. While the Lakeview proposed course was offered as a viable choice for fulfilling the online learning requirement, it was necessary that the course also met the state's experiential learning guidelines. The MDE Pupil Accounting Manual specifies these guidelines at http://www.michigan.gov/documents/mde/Section 6 Work Based Edu.Programs 199028 7.pdf. This document gives an example of a Librarian's Assistant Course that would satisfy experiential learning guidelines. In such a course, a pupil would receive curriculum-based instruction from the certificated teacher that has been approved by the local board. The pupil would be given a syllabus, tests and quizzes, and the pupil would be eligible to receive credit towards a high school diploma through the issuance of a grade. Table 2 summarizes the Guidelines for Experiential Learning Courses and also reviews the Core Principles and Essential Characteristics of Online Learning which can be found in the Online Experience Guideline Companion Document (cited in Table 1). These Guidelines, Core Principles and Essential Characteristics were all addressed in the design of Lakeview's Introduction to Information Literacy course.

\footnotetext{
* CareerForward, http://cfwd.mivu.org/
} 
Table 2

State of Michigan Guidelines for Introduction to Information Literacy Course

Guidelines for Experiential Learning Courses

Core Principles and Essential Characteristics of Online Learning

The pupil must be enrolled in grades 9 to 12 .

The course is supervised by a certificated teacher.

The primary responsibility of the certificated teacher of the course is teaching the pupil(s) during the course time frame.

A grade and credit must be given based upon assessment.

Attendance must be taken and documented.

The experience must be a local school district board approved curriculum/course.

The board approved curriculum and course must have identifiable content standards and expectations and must be progressive in nature.

The learning objectives shall not be general employability skills, such as punctuality and developing good work habits.

The experiential learning course shall not be used solely as the one course requirement for eligibility to participate in dual enrollment.

The pupil is limited to one experiential learning course per semester.

The pupil shall not replace an employee.

The course is a combination of instruction and direct experience.
Be organized in a coherent, sequential manner.

Have instructional goals, objectives, strategies, and assessments that are aligned with state standards, benchmarks and expectations.

Is comparable in rigor, depth and breadth to traditionally delivered curriculum.

Include the principles of Universal Design for Learning by providing multiple approaches to meet the needs of diverse learners.

Be relevant and address many learning styles.

Include asynchronous and/or synchronous interaction between teacher and student, and student-to-student.

Include teachers who are knowledgeable in web-based instruction techniques.

Incorporate resources outside the classroom.

Include a monitoring plan.

Represent a collaborative experience between students and be integrated.

Show sustainability and life-long learning skills.

Include teacher involvement and online safety and ethics. 


\section{Backward Design and Course Content}

Because the Introduction to Information Literacy course contained a written curriculum that could be assessed and that adhered to MDE guidelines, the Lakeview Board of Education approved this course for implementation during the school year 2007-2008. The Lakeview School District's backward design process, based upon the model of Wiggins and McTighe (2001), provided a framework for curriculum work, assessment, and instruction. Criteria were identified for selecting big ideas worthy of deep understanding. Strategies were devised for framing units of study around essential questions. The course outline can be accessed at http://mltoolbox.org/unitcreator/printable.taf?dbouc unit uid1=697\&lesson id from the District website where the course alignment with ALA Information Power Standards and with METS can also be seen. Table 3 highlights the big ideas, enduring understandings and essential questions that have guided instruction. Figure 1 offers a summary of unit topics which support the inquiry process in the information literacy course.

Table 3

Course Overview: Introduction to Information Literacy

\begin{tabular}{lll}
\hline Big Ideas & Enduring Understandings & Essential Questions \\
\hline $\begin{array}{l}\text { Information } \\
\text { literacy }\end{array}$ & $\begin{array}{l}\text { Libraries in America, offering both } \\
\text { traditional and electronic materials, are } \\
\text { cornerstones of the communities they } \\
\text { serve. }\end{array}$ & $\begin{array}{l}\text { How do we learn to effectively and } \\
\text { efficiently access and use information } \\
\text { while also evaluating resources } \\
\text { critically and competently? }\end{array}$ \\
$\begin{array}{l}\text { Independent } \\
\text { learning }\end{array}$ & $\begin{array}{l}\text { Libraries provide access to the books, } \\
\text { ideas, resources, and information that are } \\
\text { imperative for education, employment, } \\
\text { enjoyment, and self-government. }\end{array}$ & $\begin{array}{l}\text { How can libraries encourage an } \\
\text { appreciation of literature, a desire to } \\
\text { independently seek information and a } \\
\text { commitment to lifelong learning? }\end{array}$ \\
$\begin{array}{l}\text { Social } \\
\text { responsibility }\end{array}$ & $\begin{array}{l}\text { our lives, offering an incredible wealth of } \\
\text { resources. We feel overwhelmed by this } \\
\text { information overload and explosion of } \\
\text { knowledge. }\end{array}$ & $\begin{array}{l}\text { How can the principles of freedom of } \\
\text { expression, intellectual property rights } \\
\text { and responsible technology use best be } \\
\text { upheld? }\end{array}$ \\
\hline
\end{tabular}

Procedures \& Blackboard

Organization \& Dewey Decimal

Library as a Social Institution

Banned Books Week

Library of Congress
Destiny \& MeLCat

Web Information Searches

Internet Safety and Netiquette

Online Databases

Website Evaluation
Plagiarism, Citation, Copyright

Ethical Issues

Letters About Literature

Teen Services

Pathfinder Final Project

Figure 1. Unit topics supporting inquiry process. 


\section{Course Expectations for Library Assistants}

In addition to being enrolled in a course about Information Literacy, students would still fulfill a traditional role of being a library assistant. It was important to provide a combination of routine and challenging tasks so that job satisfaction could be maximized (Bradshaw, 2006). Each student worker, therefore, had an individual responsibility beyond the more mundane work of circulation duties and shelf reading. For example, one library assistant maintained book review request files while another student processed interloan items received through the library's participation in MeLCat, the state-wide resource sharing network. Student assistants took pride in their increased knowledge about library and information resources, developing a sense of ownership of the school library media center (Lagesten 2007). They were expected to use their time efficiently and to work independently (Schipman, 2006). Job skills such as punctuality and a willingness to be of service were emphasized (Sproul, 2006). Because student assistants knew that their help was greatly appreciated, they promoted the media center in a positive manner and functioned as a group of front-line library ambassadors (Yutzety, 1998). Figure 2 summarizes examples of the more traditional tasks performed by library assistants.

Checkout of materials using automated circulation and security systems.

Shelving books and maintaining several library shelves in good order and correct numerical sequence.

Aiding students and staff in locating materials through online catalog and electronic resources.

Being available to help users with Microsoft Office and applications installed on library computers.

Assisting with simple repair of old materials and processing of new materials.

Operating AV equipment: video and digital cameras; library presentation system; laminating machine.

Figure 2. Examples of traditional tasks performed by student library assistants.

\section{Blackboard Learning Management}

An essential part of the course design process was the choice of a content management system. The Lakeview School District was able to benefit from a free offer to use Blackboard Learning Management. The Calhoun Intermediate School District (CISD), affiliated with the local REMC, paid for licenses and support costs. Some 4,000 student and staff Blackboard accounts, at a cost of $\$ 4.50$ per active user, were made available to schools in Calhoun County and nearby Branch County during the 2007-2008 school year. Blackboard professional development trainings, moreover, were provided to area educators by CISD staff. Lakeview personnel, involved in online learning projects, also participated in a web-based professional development course on "The Virtual Classroom" offered by LearnPort ${ }^{\circledR}{ }^{\dagger}$ at Michigan Virtual University. Additional familiarity with Blackboard on the part of the Lakeview High School Library Media Specialist came about through her affiliation with the School of Information and Library Science at San José State University where she taught a distance course on School Library Media Centers in fall 2007.http://slisweb.sjsu.edu/courses/233.lincoln/233fa07gs.htm

\footnotetext{
† LearnPort, http://mi.learnport.org/
} 
Although Blackboard was utilized in the design process for Introduction to Information Literacy, an earlier prototype for the course had been piloted during the previous school year. In 2006-2007, a similar blended online/onsite course for student library assistants was set up at http://lspartan.learnerblogs.org/ Figure 3 provides a screen shot of LHS Pathfinders that was created as a weblog facilitating student research and online learning.

\section{LHS Pathfinders}

A weblog facilitating student research and online learning Bigger Smaller : Left : Justify : Right : Bookmark Print Shelving and Dewey Decimal System Welcome LHS Library Assistants!

We are very glad that you will be working as a library assistant during second semester 2006-07 at Lakeview High School. This course has been redesigned so that you will not only acquire practical experience in library operations but you will also engage in a project-based learning activity to help develop 21st century information literacy skills. The knowledge gained from this course will enhance your lifelong personal and professional use of libraries and information resources.

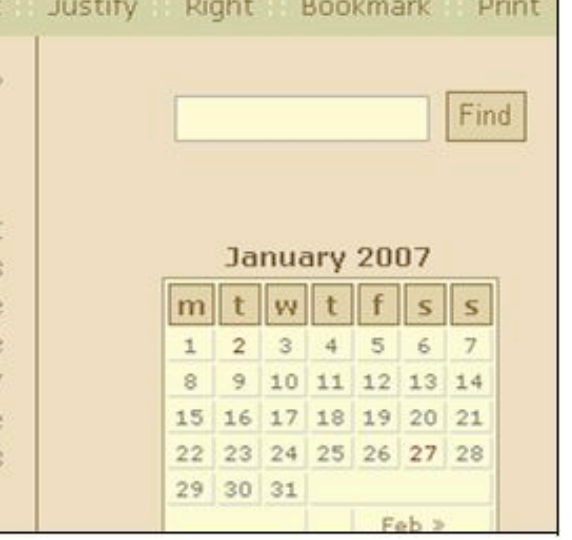

Figure 3. LHS Pathfinders weblog at http://lspartan.learnerblogs.org/

\section{Implementation of Information Literacy Course}

\section{Coursework and Assignments}

Following this prior successful run of the weblog-based course, Introduction to Information Literacy was officially launched with the start of the fall semester 2007 at Lakeview High School. Students enrolled in the course included three seniors and one junior, all of whom had a genuine desire to be involved in this new curricular offering in a blended online learning environment. They were curious to gain some behind-the-scenes library and research experience which they felt would be beneficial as they continued on to college. During the first days of school (i.e., in face-to-face meetings), library assistants reviewed the course syllabus and were given login instructions to access the course site at http://lakeview.gennet.us/ They quickly became comfortable navigating the components of Blackboard.

Library assistants regularly checked the Announcement section of Blackboard which often incorporated and modeled Web 2.0 writing tools. For example, the WELCOME announcement displayed in Figure 4 was created by means of Spell with Flickr at http://metaatem.net/words/. Students then proceeded to the Course Documents section (Figure 5) where organized folders contained materials needed for completion of weekly assignments. The contents of the Course Document folder for Week 1 are shown in Figure 6. 


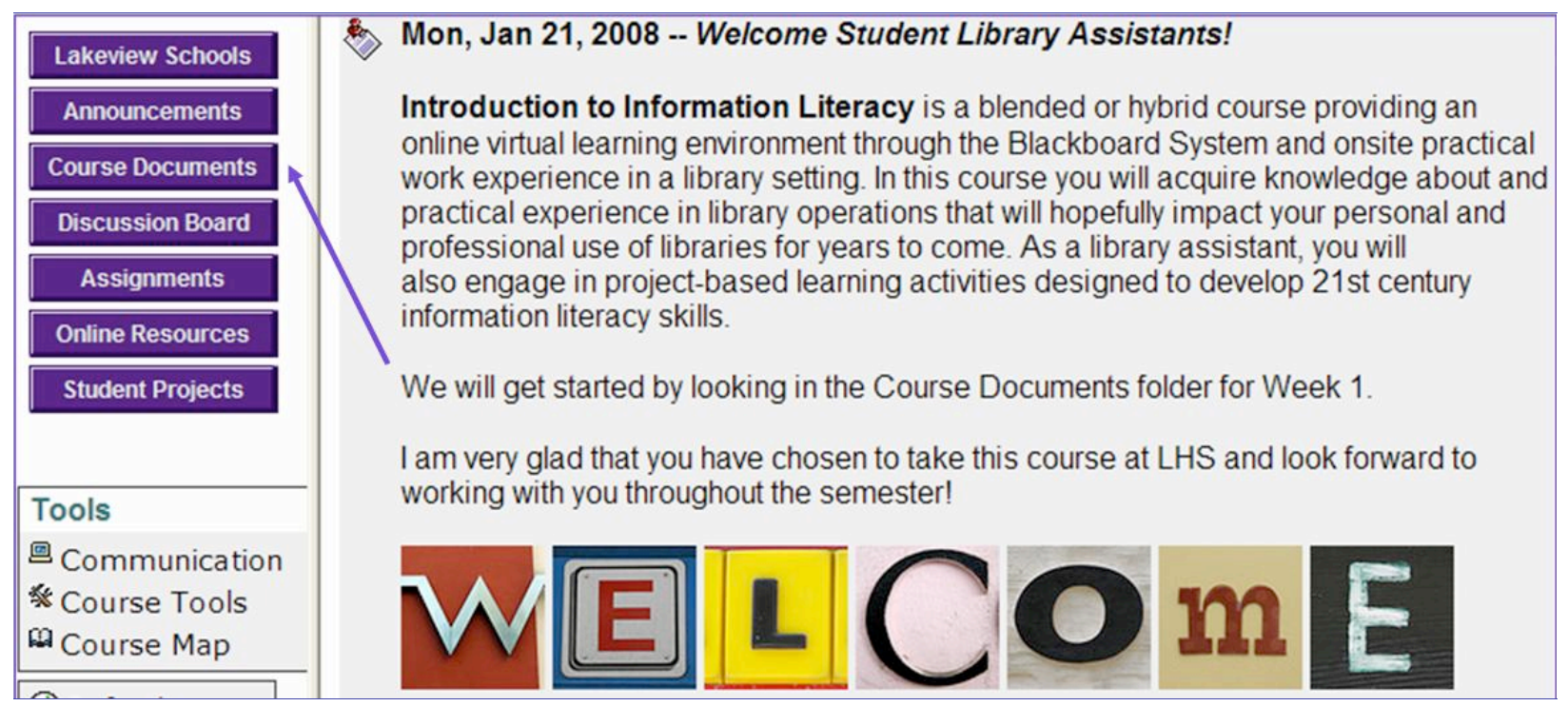

Figure 4. Announcement section on Introduction to Information Literacy Blackboard course.

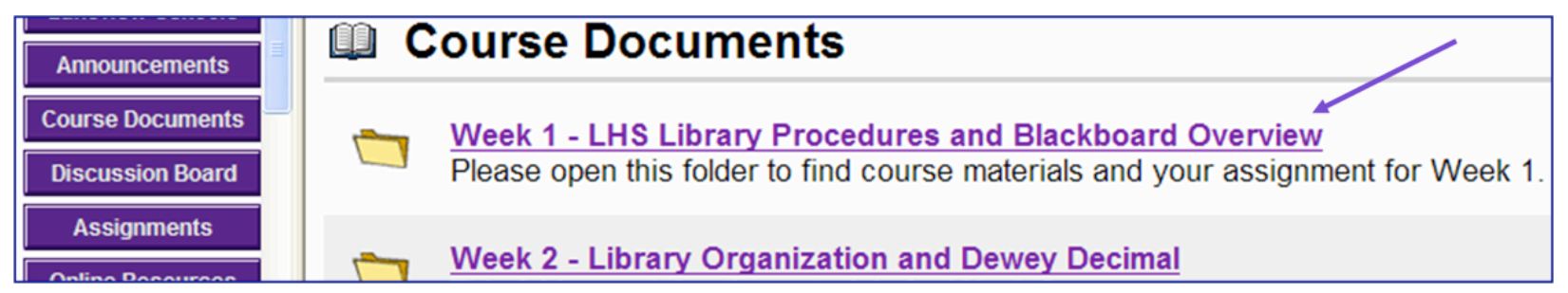

Figure 5. Course Documents folders containing materials for weekly work.

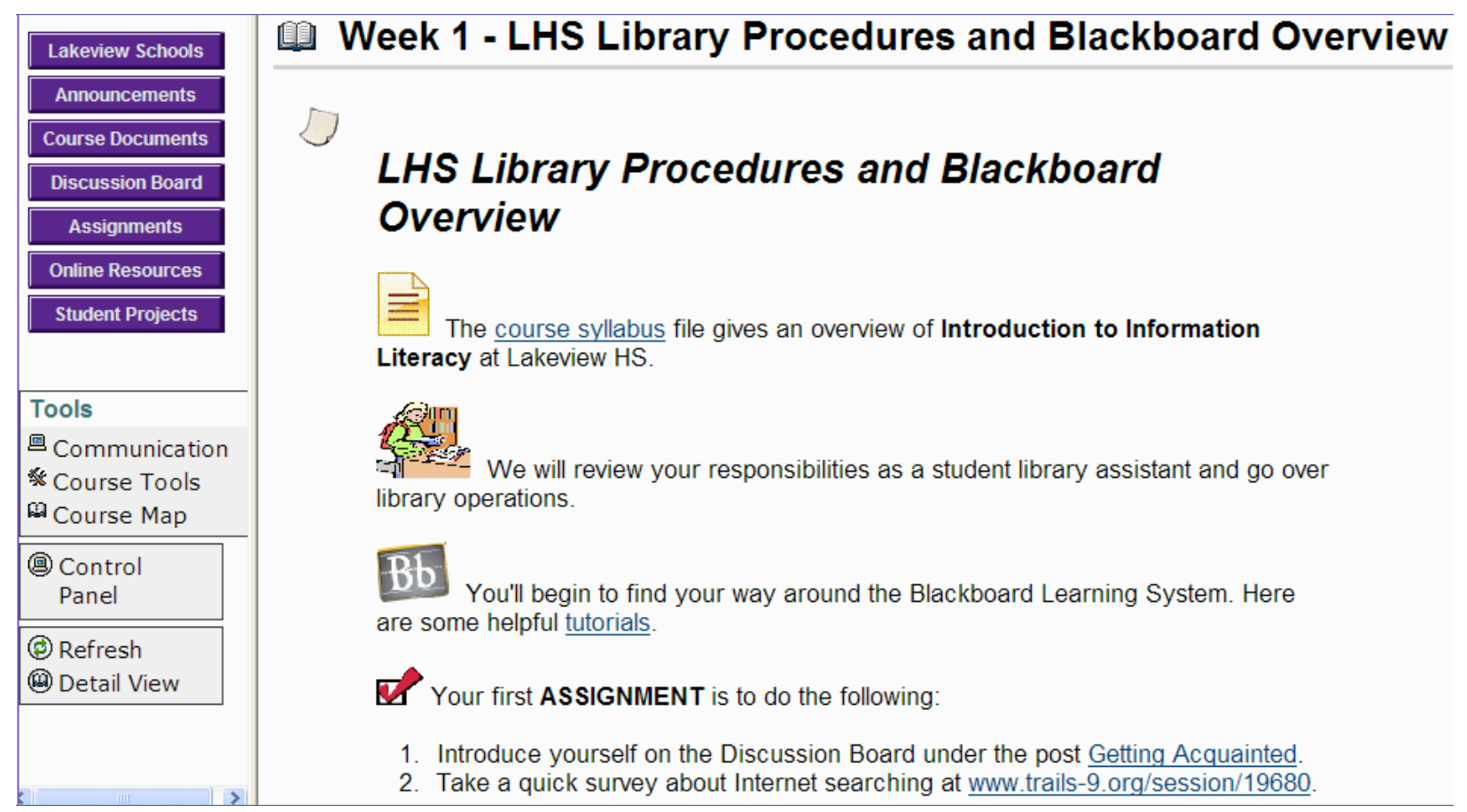

Figure 6. Week 1 Course Document folder. 
In completing weekly assignments, students often responded to prompts on the Discussion Board of Blackboard. The topic for Week 12, for example, dealt with Ethical Issues and involved a lively exchange of comments on questions of right and wrong in the online world. Is it permissible to check email at school for personal use? Which Internet sites should be blocked on a school's server? What consequences result from sharing login and password information? Can you download online images for school projects as long as you cite the source? As long as the library has a subscription to an online database, are you permitted to cut and paste portions of articles into your research paper? Because student assistants were scheduled in the library media center for different class periods during the school day, they did not access the Blackboard site at the same time. This resulted in an asynchronous form of threaded discussion for communication. The topic of ethical issues/Internet safety along with the use of an online discussion forum thus served to fulfill certain Core Principles and Essential Characteristics of Online Learning set forth in the MDE Online Experience Guideline Companion Document (MDE, 2006b) and listed in Table 2.

Other assignments completed by students involved uploading files to the Assignments section of Blackboard. A special effort was made to share quality work submitted by library assistants through the Student Projects section of Blackboard. Figure 7 shows informational posters that explain key copyright guidelines impacting teaching and learning at Lakeview High School. Figure 8 includes bookmarks created by students to illustrate the classifications of the Dewey Decimal System. Whenever possible, student work was also physically displayed in the library media center.
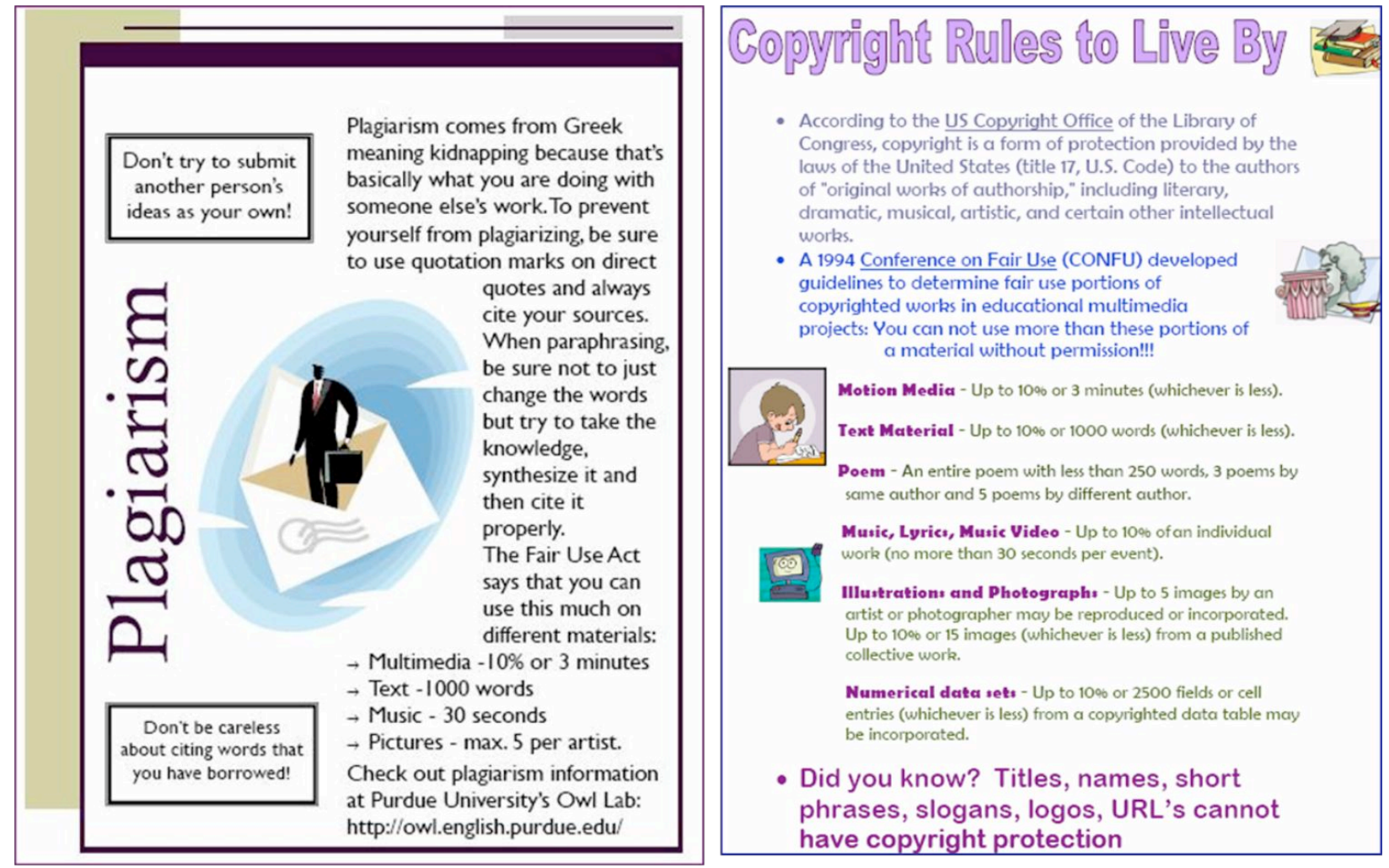

Figure 7. Posters explaining copyright guidelines. 

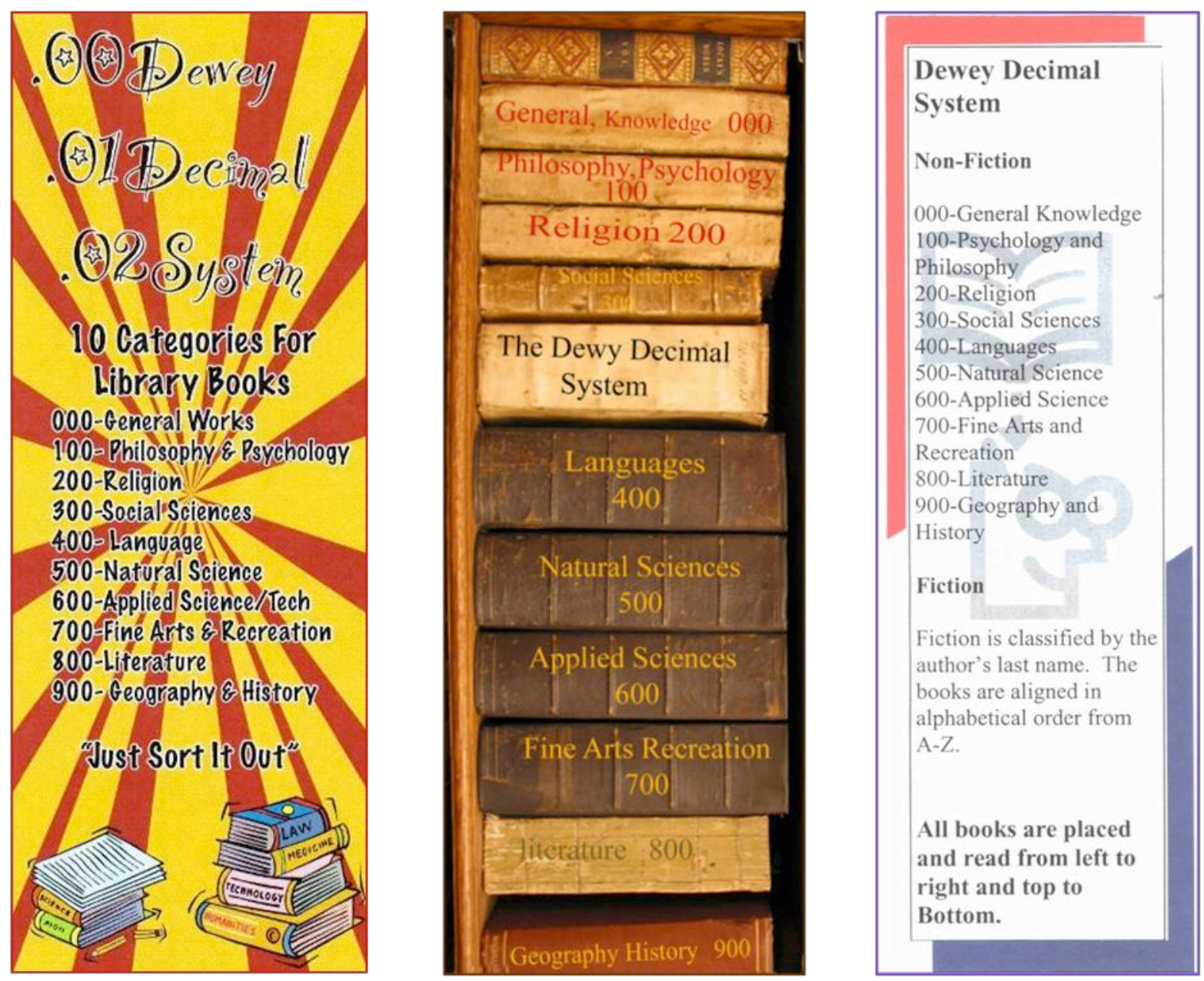

Figure 8. Dewey Decimal System bookmarks created by student library assistants.

\section{Course Evaluation}

Student library assistants completed an online evaluation of Introduction to Information Literacy at the conclusion of the course. One survey question asked students to identify the assignment which they enjoyed the most. Students consistently selected assignments that had real world applicability and that brought them a sense of accomplishment. One student, who entered the Library of Congress Letters About Literature contest as part of a Blackboard assignment, became one of three state winners from Michigan in a program that saw over 59,000 submissions nationwide (Michigan Department of History, Arts and Libraries, 2008).

In another assignment earning high marks, students first explored the topic of book challenges by means of the ALA website and through newspaper articles documenting a series of local attempts to pull books from the shelves of Battle Creek area libraries. Students then drafted a Letter to the Editor of The Battle Creek Enquirer explaining why it was important to observe Banned Books Week (September 29-October 6, 2007) in the community. The newspaper published several letters in its issue of Sunday, October 7, 2007, thereby giving recognition to Lakeview High School students for their well-reasoned and thoughtful reflections. See Figure 9. 


\section{YOUR OPINIONS}

(EDITOR'S NOTE: The following letters were submitted by Lakeview High School students enrolled in "Introduction to Information Literacy," an online hybrid course using the Blackboard Content Management System.)

Banned Books Week celebrates freedoms Did you know that Sept. 29-Oct. 6 was Banned Books Week in our community? Banned Books Week is not only celebrated by our community but is supported by the American Library Association and various other professional organizations.

Banned Books Week is all about people celebrating the freedoms that they have with their reading material. Over the years there have been many attempts to exclude books from libraries due to questionable content. Twelve years ago in our community, there were battles over books in the school libraries. In a particular elementary school, a parent attempted to get a book about witches and Halloween out of the school library.

Although she was unsuccessful in getting the book out, we as a community need to look deeper into what the effects of censorship of material can do to a community. If we start eliminating material bit by bit for reasons of inappropriate content and other various reasons, who is to say that in the future that people won't start eliminating other irreplaceable information from our libraries?

Libraries are places meant for everyone and anyone who is in need of information or people who simply want to relax while reading a good book. A library should be a safe haven of information. How can a person feel comfortable knowing that at any time someone can put a stop to his or her learning opportunities? So in conclusion, Banned Books Week helps make people aware of what they have and what they could lose.

\section{Katelynn Wright}

We have right to intellectual freedom I believe that it is important to recognize Banned Books Week. This gives an opportunity for people of all backgrounds to read what they want. Every American citizen has the right to freedom of thought and freedom of speech. A book should not be banned for some reference to sex, or some violence. In other words, every citizen should have the right to intellectua freedom. Intellectual freedom gives every individual to both seek and receive information from all points of view without restriction.

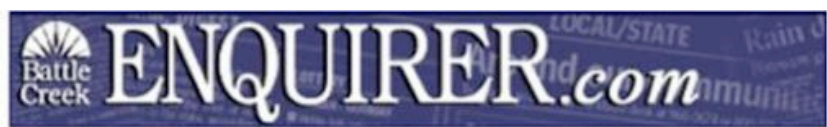

Sunday, October 7, 2007

Looking back in 2006, the primary reason for banning books was based on sexual content and offensive language. I think that the American people need to open their eyes and look at all of the movies that came out in 2006. If parents are that worried about what their children read, they should also keep less of a closed eye on what their children are watching. Personally, I would rather have my child become aware of the violence, sex, drug use, etc. in a book rather than a movie and actually seeing those actions being done.

Banned Books Week has been observed since the year 1982, supported by the American Library Association and other professional organizations. Since that time, there has been quite an increase in technology. With the growth of the Internet, all barricades are broken down and children are being thrown into the world of online chat with complete strangers and exposure to pornography. A person who reads a book cannot help but learn something rather than just stare at a screen as do most American citizens today. Being glued to a computer screen or a television screen does not require the same mental concentration as does reading a book.

Yes, parental controls should exist. But what is this world coming to if a person cannot read a certain book because of a reference to some inappropriate subject? I could have sworn we were America, the land of the free.

\section{Lacey Wiseman}

Don't take freedom of choice for granted Banned Books Week, where people celebrate the freedom of choice and expression even if that clashes with the mainstream idea, was observed Sept. 29 Oct. 6. This week represents a fundamental personal freedom.

In the Lakeview School District, there were problems with book challenges and issues involving "inappropriate" books in 1994 and 1995. Reading articles in the Enquirer from that era sparked feelings of anger. I was reminded of McCarthyism and the Salem Witch Trials: periods of fear, skepticism and confusion. Needless blame was placed on innocent shoulders, when the real problem rested on the insecurities of the accusers. It was a mass bandwagon of confusion where many innocent bystanders were run over.
Parents are concerned about their 14- and 15 -year-old children being exposed to "negative influences." Society today is much different than 20 years ago. Profanity, sex and gore have become more acceptable in today's society. Fewer words have been "bleeped" due to loopholes, "closeness" is promoted because sex sells, and gore makes entertainment scarier.

Something parents also need to know is that libraries don't blindly choose books. There is an awareness of each book within the library (especially in school libraries). With the availability of MeLCat (the statewide resource sharing network), library staff at Lakeview High School also review and screen interloan requests ordered by students.

Books depicting witches, superheroes and fantasy creatures are often challenged. It is argued that "supernatural" literature pieces are too frightening and have satanic religious elements. Novels such as "Harry Potter," "A Wrinkle in Time" and "James and the Giant Peach" are among the top contested books. These stories don't encourage kids to practice witchcraft or the black arts; they entertain and provide a safe, enjoyable form of recreation.

Adult themes are also a source of contention. Works such as I" Know Why the Caged Bird Sings," "The Adventures of Huckleberry Finn," "Of Mice and Men," "The Catcher in the Rye," "To Kill a Mockingbird," "Lord of the Flies," "Flowers for Algernon" and other acclaimed titles are most frequently on the hit list. I was taken aback by challenges to Nobel and Pulitzer Prize winners. People are so caught up in their own insecurities that they miss the great literary talent of notable authors.

The novels that have been the most challenged are out on display for the world to read during Banned Books Week. This isn't a Lakeview School District thing but a nationwide event. It celebrates a freedom that we take for granted. Banned Books Week should be promoted. If you are opposed, then don't involve yourself, but if you are interested, then you should have the right to express that desire, and you will be more than welcome to come and read.

William Long

Figure 9. Letters to the Editor from Lakeview High School students. 
Students were formally assessed by means of the online tool TRAILS discussed earlier. Fall term library assistants only participated in a posttest, administered at the end of the semester. However, second term library assistants were to be tested at both the start and conclusion of the semester. As part of the course evaluation survey, library assistants were asked to supply their definition of an information literate student as seen in Figure 10. The TRAILS data and student feedback will be used to suggest changes and improvements in any restructuring of the Introduction to Information Literacy course for the 2008-2009 school year.

A student who is information literate would know how to do research, find books based on a certain topic, and understand copyright and plagiarism. If you can do those things correctly, then you know how to handle information.

Based on my experience in this course, the qualities a student must have to be information literate include knowing how to search the Internet rather than just doing a Google search! It is important to know how to broaden or narrow your search to get the information which you need. You should be familiar with your school's databases and understand MLA citation format.

A student who is information literate is someone who is able to use resources to the best of their ability. They are able to use a source and find their information without much struggle. An information literate student is a productive user of the Internet and capable of safely researching in an intelligent way.

I would say that modest and informed would be the two top characteristics of an information literate student. You learned many different things and ideas throughout this course. You gained a level of leadership, respect, compassion, and confidence. You now have the information necessary to guide those who need assistance.

Figure 10. Information literacy defined by Lakeview High School library assistants.

\section{Dissemination of Online Course Experience}

Before looking ahead to modifying Lakeview High School's first blended online course, it is worth mentioning efforts to disseminate results of this year's Blackboard experience. How were Lakeview classroom teachers able to benefit from the library media center's venture into online learning? What attempts were made to reach out to school library colleagues involved in similar online library media curriculum projects?

Collaboration with colleagues was an essential priority for this school year in the interest of impacting student achievement (Haycock, 2007; Rosenfeld, 2007). The library media specialist worked with fellow teachers to incorporate various online information literacy activities from the Blackboard course into instructional units taught in other academic departments at Lakeview High School. For example, as part of an assignment for a unit focusing on Web 2.0 tools (coinciding with the observance of Teen Tech Week, March 2-8, 2008), library assistants in the Blackboard course learned how to set up Blogline accounts (Figure 11). Students in a Global Economics course then engaged in a similar project, co-taught by the classroom teacher and library media specialist. Students created aggregators to bring in news feeds and also 
search alerts from the library's subscription databases. The Global Economics course is designed to provide students with knowledge and tools needed to make rational economic decisions for themselves and our nation while also developing critical thinking skills with which to address the challenges and complexities of globalization. The inclusion of the Bloglines project allowed students to demonstrate mastery of technology tools for accessing information and pursuing inquiry as set forth in standard 1.1.8 (AASL, 2007). As more online instructional activities of this type are added to Global Economics, the course is being considered a possible means to fulfill the MDE 20 hour online learning requirement at Lakeview High School.

\section{RSS}

RSS stands for "Really Simple Syndication" or "Rich Site Summary." It is a file format for delivering regularly updated information over the web. You no longer need to daily visit websites and news information sources. It takes time to visit those sites and scour the ad-filled and image-heavy pages for new content. Instead, you can create a free RSS aggregator account or news reader using Bloglines.

- View RSS in Plain English, a video by Common Craft http//commoncraft com/rss plain english

- Add RSS Feeds to Bloglines at http//www youtube com/watch?v=pKGz-y SGL4 is also helpful.

- Using Bloglines Tutorial at http//preetamrai com/weblog/?s=bloglines+tutorial shows how to set up a Bloglines account on. This tutorial has been adapted here for use at Lakeview High School.

\section{Signing Up}

a. Sign up for an account at http//www. bloglines.com. Click Sign up now - It's free!

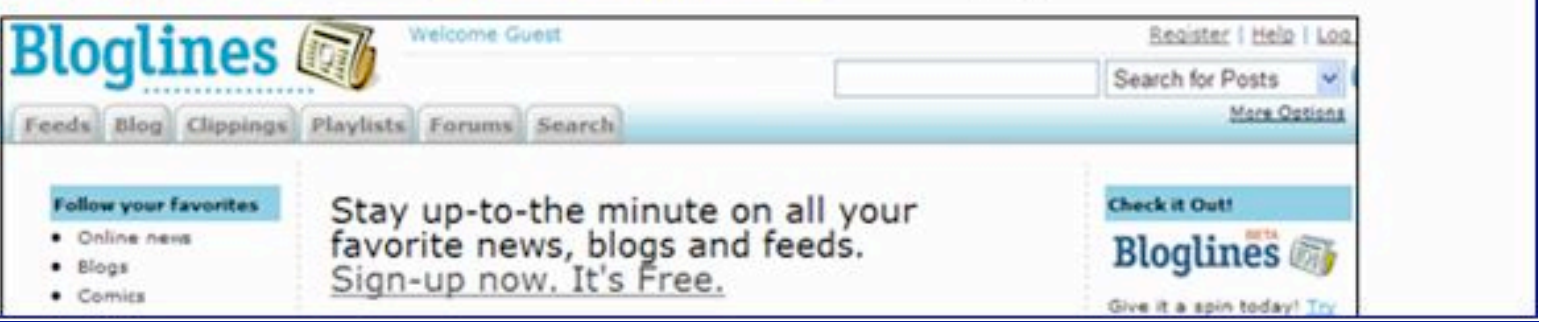

Figure 11. Instructions that were given to students for setting up a Bloglines account, available at http://www.lakeviewspartans.org/webpages/mlincoln/files/BloglineBlackBd.doc.

Other opportunities for lesson collaboration and information literacy skills integration occurred as English classes undertook the traditional major research paper assignment. Instead of delivering a one-time lecture about library materials, the media specialist offered more in-depth guidance in finding, selecting and evaluating information resources along with background on source citation. This instruction was provided face-to-face during class time but was also reinforced through online tutorials and guides which were developed by the library media specialist and which students could access independently (Figure 12). An enduring understanding of the research paper assignment is that building an effective argument hinges on the organization and synthesis of credible researched materials. Thus, according to standard 2.1.1 (AASL, 2007), students continue an inquiry-based research process by applying critical-thinking skills (analysis, synthesis, evaluation, organization) to information and knowledge in order to construct new understandings, draw conclusions, and create new knowledge. 

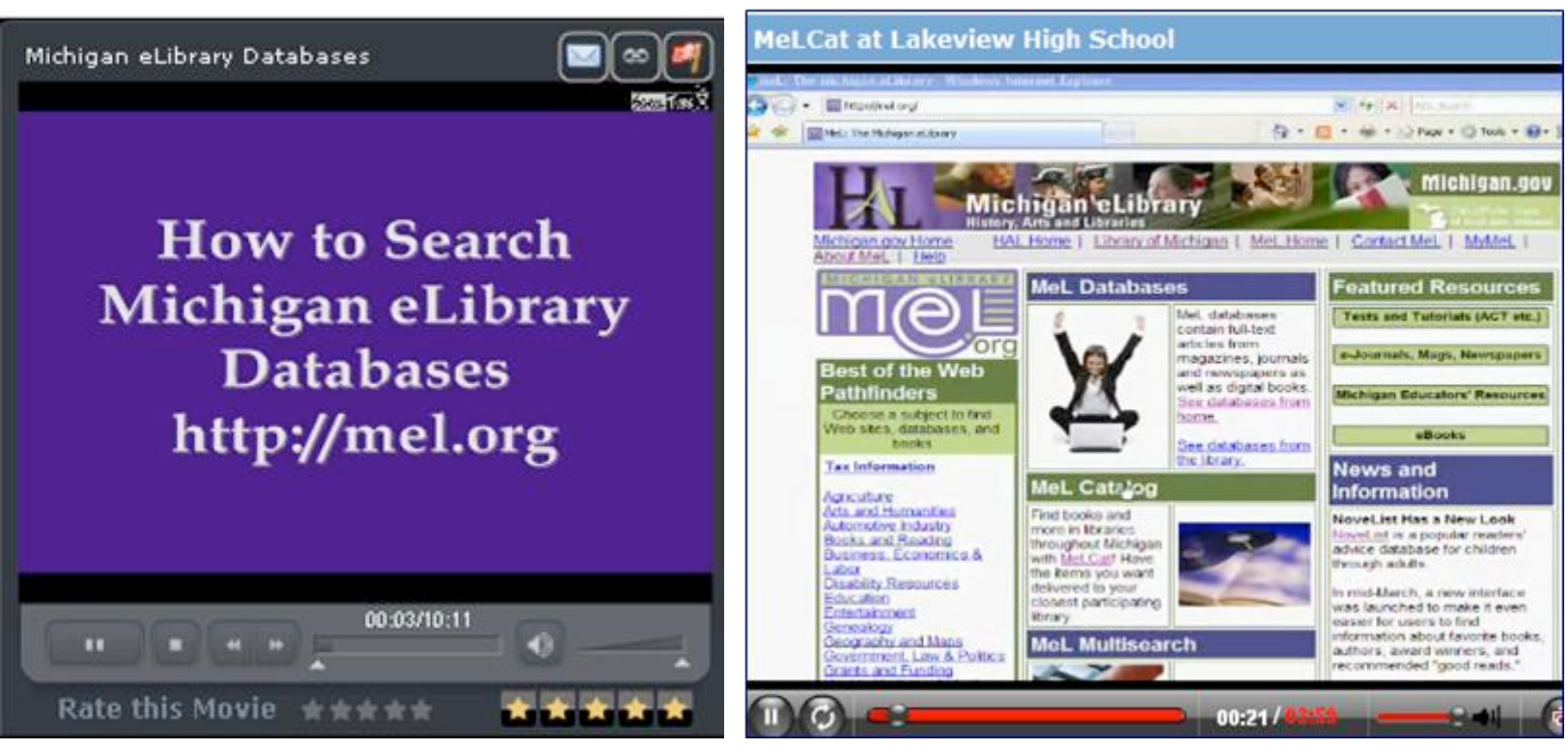

Figure 12. SchoolTube and TeacherTube instructional videos about Michigan eLibrary databases and MeL Catalog are available at http://www.schooltube.com/default.aspx?vid=6240 and at http://www.teachertube.com/view video.php?viewkey=4c475f4729d0e2b42a14.

Collaborative efforts in the online learning environment extended beyond Lakeview High School. The networking resources of the Michigan Association for Media in Education (MAME) were called upon to connect with other school library media specialists in the state who might be piloting their own versions of a comparable online information literacy course. A message was posted on the MAME listserv resulting in several responses from colleagues willing to share experiences. Online library media courses have been developed for student assistants (Carmen Ainsworth, North Branch, and Brandon High Schools) but also for entire groups of students such as the freshmen class (Grosse Pointe North High School). Both Moodle (Figure 13) and Blackboard (Figure 14) are being used to deliver course content.

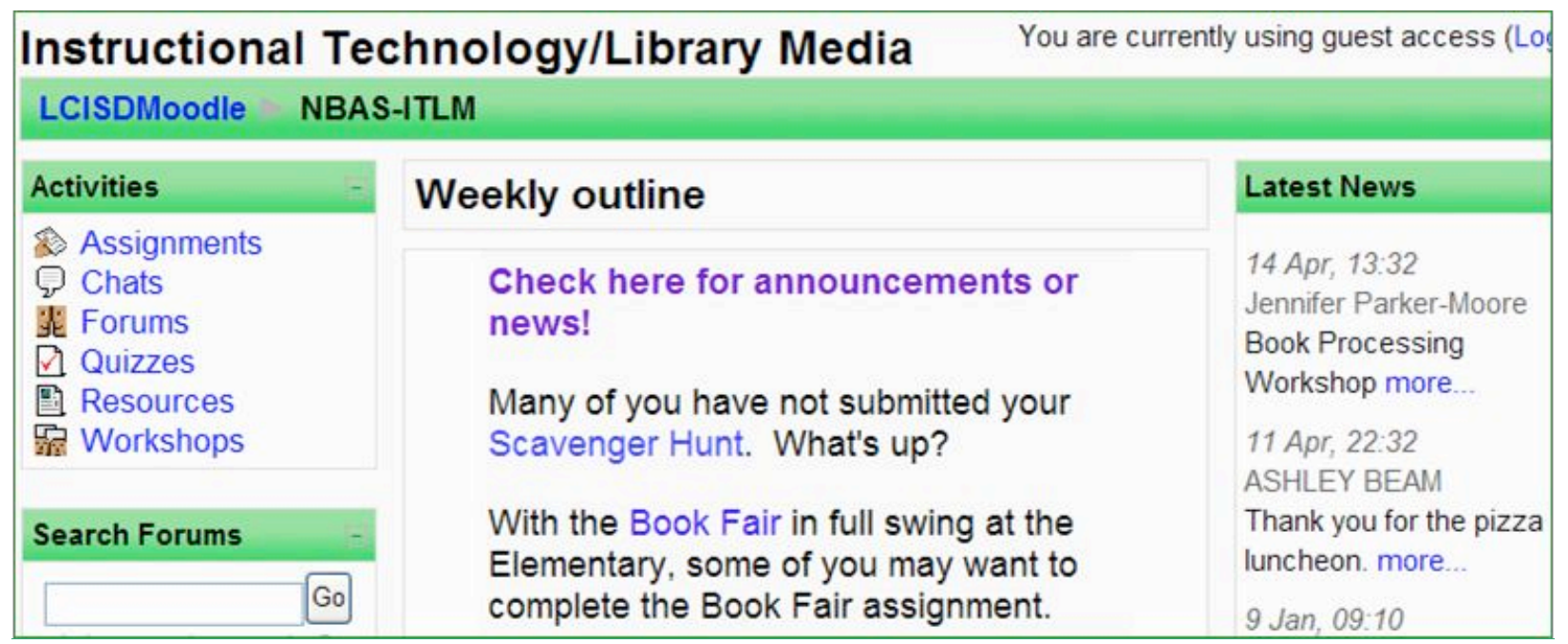

Figure 13. Announcement on North Branch Area Schools Moodle course site. 


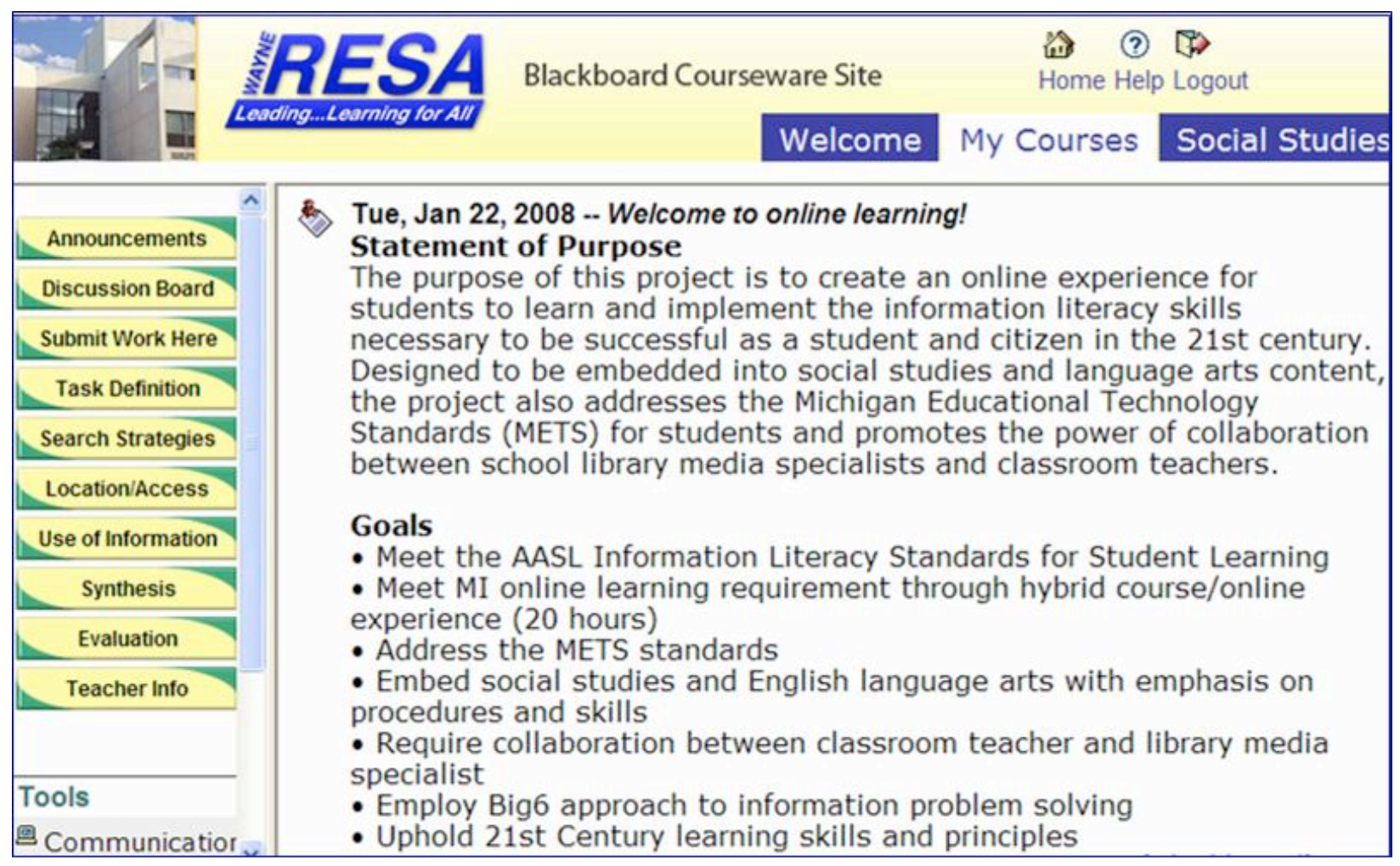

Figure 14. Announcement on Grosse Pointe North High School's Blackboard course site.

Exchange of ideas, suggestions for online course content, and plans for possible joint projects between schools are already taking place. Table 4 gives contact information and brief overviews for these Michigan providers of online library media courses. Figures 15 and 16 show screen shots of a wiki set up at http://remc12.wikispaces.com by Lakeview High School Library to facilitate development of additional online courses that promote information literacy skills.

Table 4

Library Media Curricula in Michigan

Contact Information Course Title and Description

Andrea Atkinson

Carman-Ainsworth High

School

aatkinso@carman.k12.mi.us
Media Apprentice: In order to promote information literacy skills and to maximize library use, this course provides students the opportunity to partake in an experiential learning course that coincides with the individual EDP. This course provides an online learning experience, reinforces the Michigan High School content expectations of Technology, English Language Arts, and Career and Employability Skills and incorporates the Information Literacy Grade Level Expectations as outlined by the American Library Association. A Blackboard course.

(table continues) 
Table 4 (continued).

Contact Information

Jennifer Parker-Moore, Ed.D

North Branch Area Schools

jpmoore@,nbbroncos.net

Sarah Sindelar

Brandon High School

ssindelar@,brandon.k12.mi.us

Karen Villegas

Grosse Pointe North High

School

Karen.Villegas@gpschools.org
Course Title and Description

Instructional Technology/Library Media: Students will develop information and technology literacy using the Big6 Model in a library media environment. Students will develop a working knowledge of library operations and become comfortable with search strategies using online databases, materials acquisition, circulation and patron relations, library operations, and research skills. This course teaches information problem solving strategies for lifelong learning. A Moodle course.

Introduction to Information Skills: This class is designed to introduce the college bound student to the concepts of information literacy. Living in the information age students are often competent surfing the web, but have great difficulty finding credible authored, edited, published information on a given topic in a reasonable amount of time. This course aims to familiarize the student with the daily operations of the library, MARC records, interlibrary loan, building search strings and queries, advanced web searching, Boolean operators, webpage evaluation, in-depth database searching, copyright, fair use, citing sources, plagiarism, information literacy models, and the profession of librarianship. Students will experience four books in print or audio format and will create book reviews to share with the BHS community. Students accepted into the course will need to display a high degree of self-direction. A Moodle course.

GPN - Information Literacy: This course was conducted over a two-week period for all freshmen in 2007-2008. The purpose of the project was to create an online experience for students to learn information literacy skills necessary to be successful as a student and citizen in the 21 st century. Designed to be embedded into social studies and language arts content, the project addressed AASL Information Literacy Standards for Student Learning and the Michigan METS while promoting collaboration between school library media specialists and classroom teachers. The course meets the Michigan online learning requirement and employs the Big6 approach to information problem solving. For the next school year, the curriculum will be incorporated into a new "Digital Seminar" that focuses on digital communication. $A$ Blackboard course. 


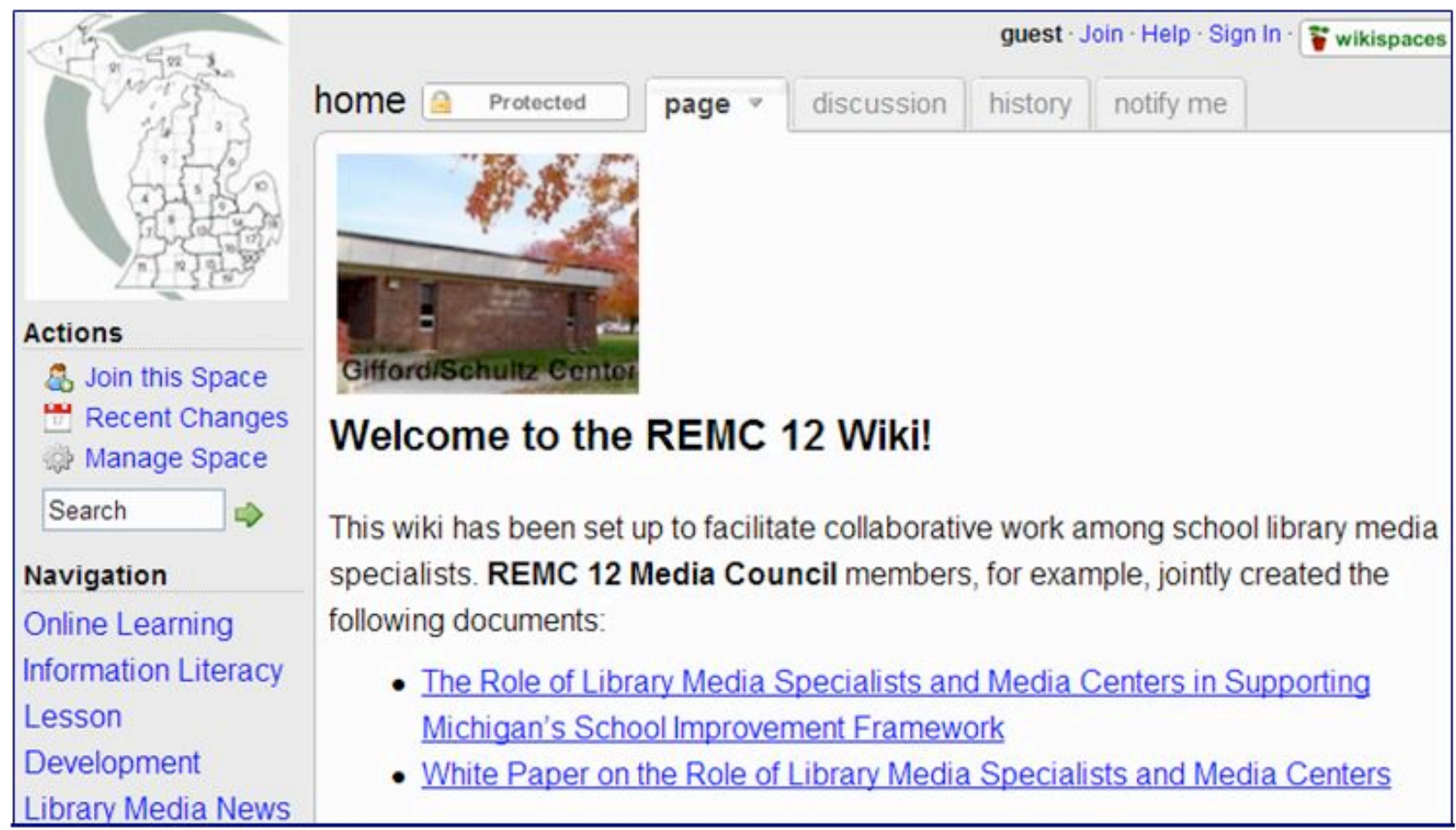

Figure 15. REMC 12 wiki set up to promote collaborative efforts in online learning.

\section{Activities, Projects, Tutorials}

- ACRL Tutorials: from the Association of College and Research Libraries

- Information Literacy \& You» modules from Penn State Penn State

- Information Literacy Resources $\$$ from Carnegie Mellon

- Information Seeking Skills Go for the Gold ' from James Madison University

- Interactive Tutorials from Vaughan Memorial Library, Acadia University,

- Library/nfo Literacy ${ }^{\circledR}$ course modules from Minneapolis Community and Technical College

- Library Quia Quizzes ${ }^{2}$

- Library Skills Shambles 2

- Library Skills Tutorial $₫$ from Glascow University Library

- Library Video Tutorial $\$$ from Brown University

- Searchpath ${ }^{2}$ information literacy tutorial from Western Michigan University

- Student Learning Packets ${ }^{\circledR}$ from San Diego State University

\section{Assessment}

- Educational Testing Service Information Literacy Test ${ }^{\circ}$ (School Library Journal article)

- Information Literacy Quiz" (Alan November)

- Oregon MS info lit test ${ }^{20}$

Figure 16. REMC 12 wiki page with online information literacy tutorials and assessment tools. 
The Common Beliefs section of the new AASL (2007) Standards for the 21st-Century Learner challenges school librarians to collaborate with others to provide instruction, learning strategies, and practice in using the essential learning skills needed in the 21 st century. Heisey and Thom (2007) concur that a vital component of any successful library media program is the formation of partnerships. Rather than working in isolation, a library media specialist must reach out to colleagues and collaboratively design, teach, and evaluate units of instruction. Library media teachers must be partners in the educational process if they want to play an integral role in curriculum, instruction and assessment. In the new online learning environment, library media specialists are creating an infrastructure to support the dynamic and evolving ways that students and teachers use information resources. Through the support of our professional organizations such as the International Association of School Librarianship and through the efforts of practitioners, school libraries are working to achieve world class learning and literacy.

\section{References}

Abilock, D. (2005). We're here! Great digital teacher-librarians. Knowledge Quest, 34(1), 8-10.

American Association of School Librarians (AASL). (2007). Standards for the 215t-century learner. Retrieved, May 6, 2008, from http://www.ala.org/ala/aasl/aaslproftools/learningstandards/AASL_LearningStandards.pdf

Armstrong, S. (2007). Virtual Learning 2.0: Professional development is a whole new ballgame for educators who teach online. Technology \& Learning, 28(4), 26-29.

Battle, J. C. (2007). Information literacy instruction for educators and the role of school and academic libraries. Texas Library Journal. 83(3), 120-2, 124-5.

Bauer, J., \& Kenton, J. (2005). Toward technology integration in the schools: Why it isn't happening. Journal of Technology and Teacher Education. 13(4), 519-546.

Bradshaw, M. (2006). Keep your student workers. Library Journal, 131(9), 44.

British Library (2008, January). Information behaviour of the researcher of the future. Retrieved February 1, 2008, from http://www.bl.uk/news/pdf/googlegen.pdf

Brown, C., Murphy, T. J., \& Nanny, M. (2003). Turning techno-savvy into info-savvy: Authentically integrating information literacy into the college curriculum. Journal of Academic Librarianship, 29(6), 386-398.

Cahoy, E.S. (2002). Put some feeling into it!: Integrating affective competencies into K-20 information literacy standards. Knowledge Quest, 32(4), 25-28.

Dando, P. M. (2005). First steps in online learning: Creating an environment for instructional support and assessment. Knowledge Quest, 34(1), 23-24.

E-Learning is everywhere. (2007). State Legislatures, 33(7), 12.

Esch, C. \& Crawford, A. (2006). Helping students make the jump to university level research. MultiMedia \& Internet@Schools, 13(2), 21-25.

Giles, K. L. (2004). Reflections on a privilege: Becoming part of the course through a collaboration on Blackboard. College \& Research Libraries News, 65(5), 261-263.

Haycock, K. (2007). Collaboration: Critical success factors for student learning. School Libraries Worldwide, 13(1), 25-35. 
Heisey, B. \& Thom, M. (2007). Partnership or collaboration? It's both in Bakersfield. CSLA Journal, 30(2), 33-34.

Ishizuka, K. (2006). Virtual High School. School Library Journal, 52(5), 22-23.

Jackson, P. A. (2007). Integrating information literacy into Blackboard: Building campus partnerships for successful student learning. The Journal of Academic Librarianship, 33(4), 454-61.

Kachel, D., Henry, N., \& Keller, C. (2005). Making it real online: Distance learning for high school students. Knowledge Quest, 34(1), 14-17.

Lagesten, C. E. (June 2007). Students as library leaders: Student team builds leadership skills while helping to battle budget cuts. Teacher Librarian, 34(5), 45-47.

Lang, J. M. (2007). Midterm grades for Blackboard. Chronicle of Higher Education, 54(13), C2-C3.

Michigan Department of Education (MDE). (2006a). Michigan Merit Curriculum Guidelines. Retrieved April 27, 2008, from http://www.michigan.gov/documents/mde/Online10.06_final_175750_7.pdf

Michigan Department of Education (MDE). (2006b). Online Experience Guideline Companion Document. Retrieved April 28, 2008, from http://www.michigan.gov/documents/mde/OE_Companion_Doc_1206_184084_7.pdf

Michigan Department of Education (MDE). (2006c). State of Michigan Technology Plan. Retrieved April 27, 2008, from http://www.michigan.gov/documents/STP2006_5-10-06c_158945_7.pdf

Michigan Department of History, Arts and Libraries (HAL). (2008). Battle Creek, Birmingham and Howell Students' 'Letters About Literature' Earn Statewide Awards, Donations for School Libraries. Retrieved April 30, 2008, from http://www.michigan.gov/som/0,1607,7-192--190761--,00.html

Novotny, E., \& Cahoy, E.S. (2006). If we teach, do they learn? The impact of instruction on online catalog search strategies. Libraries \& the Academy, 6(2), 155-167.

Pappas, M. (2002). Discussion forums: A tool for collaboration. Knowledge Quest, 31(2), 17-19.

Richardson, W. (2007). Online-powered school libraries. District Administration, 43(1), 62-63.

Rohland-Heinrich, N. \& Jensen, B. (2007). Library resources: A critical component to online learning. MultiMedia \&Internet@Schools,14(2),8-12.

Rosenfeld, E. (2007). Less is more: setting achievable goals. Teacher Librarian, 35(1), 6.

Schipman, M. (2006). It's cool to work in the library. Student library aides. Library Media Connection, 25(3), 26-27.

Schloman, B. F. \& Gedeon, J. (2007). Creating TRAILS: Tool for Real-Time Assessment of Information Literacy Skills. Knowledge Quest, 35(5), 44-47.

Scott, T. J. \& O'Sullivan, M. K. (2005). Analyzing student search strategies: making a case for integrating information literacy skills into the curriculum. Teacher Librarian, 33(1), 21-25.

Sproul, B. (2006). Implementing a library helper program is easy, economical, and energizing. Library Media Connection, 24(7), 44-46.

Tallman, J., \& Fitzgerald, M. (2005). Blending online and classroom learning environments: Reflections on experiences and points to consider. Knowledge Quest, 34(1), 25-28. 
Tomei, L A (2006). The impact of online teaching on faculty load: computing the ideal class size for online courses. Journal of Technology and Teacher Education, 14(3), 531-541.

U.S. Department of Education. (2004). National Education Technology Plan 2004. Retrieved April 28, 2008, from http://www.ed.gov/about/offices/list/os/technology/plan/2004/plan.pdf

U.S. Department of Education. (2007). Innovations in Education: Connecting Students to Advanced Courses Online. Retrieved April 28, 2008, from http://www.ed.gov/admins/lead/academic/advanced/coursesonline.pdf

West, R., Waddoups, G., \& Graham, C. (2007). Understanding the experiences of instructors as they adopt a course management system. Educational Technology Research \& Development, 55(1), 1-26.

Wiggins, G., \& McTighe, J. (2001). Understanding by design. Upper Saddle River, NJ: Merrill/Prentice Hall.

Yohe, P. (2007). Getting information literacy standards noticed: How promoting these standards just might save your job. Library Media Connection, 26(3), 28-30.

Yutzey, S. D. (1998). The evolution of a school library volunteer program [at Bishop Watterson High School, Columbus, Ohio]. Ohio Media Spectrum, 5a(2), 33-35.

\section{Biographical Notes}

Margaret Lincoln is a library media specialist at Lakeview High School in Battle Creek, Michigan, a lecturer in the School of Library and Information Science at San José State University, and a database trainer for the Library of Michigan. She earned a Ph.D. in library and information sciences from the University of North Texas in 2006. Dr. Lincoln has been honored by the Michigan Association of Media in Education and received AASL's Collaborative School Library Media Award. She has been an American Memory Fellow with the Library of Congress and a Mandel Fellow with the United States Holocaust Memorial Museum.

\section{Statement of Originality}

This is to certify that the paper above is based upon original research undertaken by the author and that the paper was conceived and written by the author alone and has not been published elsewhere. All information and ideas from others is referenced. 